\title{
The Role of Scripture and Catechesis In Evangelization
}

\author{
Rev. Fr. Dominic Obielosi \\ Department of Religion and Human RelationsNnamdi Azikiwe UniversityAwka, Anambra State, Nigeria
}

\begin{abstract}
Immediately after his resurrection but before his ascension, Christ Jesus gave a mandate to his disciples. He said poreuqe,ntej ou=n maqhteu,sate pa,nta ta. e;qnh( bapti,zontej auvtou.j eivj to. o;noma tou/ patro.j kai. tou/ ui 'ou/ kai. tou/ a 'gi,ou pneu,matoj” (going therefore make disciples of all the nations, baptizing them in the name of the father and of the son and of the Holy Spirit). The church believes this to be a perpetual imperative that defines her vision and mission to the world at large. In order to fulfil this mandate, she sees the scripture as the primary source of the teachings handed on by her founder, Jesus. She assumes the responsibility of interpreting and communicating this message of evangelization. In order words, she has the message enshrined in the inspired Word of God and then she communicates it to people through her catechesis. This paper examines the role the Scripture and Catechesis have played and still play in evangelization. The paper moves from general study of the roles and then zeroes it down to African specifics. The primary preoccupation is not so much with the impact of the missionary catechetical method. The paper takes up some notable challenges posed by aberrations sequent to misinterpretation of the bible and then postulates the best way to evangelize Africa without exploiting the ignorance of our people enrich ourselves instead of winning them for Christ.
\end{abstract}

KEY WORDS: Scripture, Catechesis, Evangelization, Role, Interpretation, Recommendations.

\section{INTRODUCTION}

"The bible is the most widely purchased, extensively read, and deeply revered book in the history of civilization. Arguably it is also the most thoroughly misunderstood, especially by the lay reading public" 1 and even by some clergy. In no age is the role of the bible in evangelization more conspicuous and pressing than in this age. No age has witnessed citation of the bible than our own time. Yet if there is a time when the role of scripture and catechesis in evangelization needs being explored it is in this age. Locally, the urgency stares all of us in the face as we are confronted daily with Biblicism and incipient fundamentalism characterizing our time. Universally, the situation is not different. Christianity has a compelling narrative inscribed into its bible, archaeology, architecture, arts and music. Whereas formerly holy men and women were presented as models to be imitated today the reverse is the case. We now live in a world of competing narratives both secular and religious. Some of the narratives deconstruct meaning while some construct meaning. Some directly oppose the foundations of our faith while some defend it. The fact is that today we exist in a world of models. More dangerous is that modeling after entertainment and sport figures is on the majority. The names people now give their newly babies prove the propensity towards this. In the field of academics, our age is a brain child of the repercussions of the age of enlightenment in Europe. The thought-lines are evident from anti-christian publications and movies all over the world. One must not forget the devastating effect on the faith of many people by the Da Vinci Code and other similar works. Some of our local movies tend to toe the same direction. Some attack the scripture directly. Some others confront the Christian beliefs and tenets. To say the least, we live in a world of competing narratives, and all of them are vying for our allegiance. Locally, Scripture is cited as an authority for virtually everything even out of context. Indeed, it is like our people are getting more and more confused. Feigned miracles fill up television screens today, all demonstrating the practicality of the provisions of the scripture. The problem comes when one cites and prays with the same passages and even more without positive result. Many Catholics have suffered ship-wreck on their faith. Some leave the church to join other Christian sects. Our younger ones in the face of frustrations and lack of hope for tomorrow, end up going back to traditional religious practices believing that it is more powerful and responsive since the church and her bible have not been able really to address his problems. Back in our villages, the shrines and idols denounced and burnt years ago when some priest and pastor crusaders visited some towns have not only been revived by our baptized youths but have even been so modernized that one thinks that it is a Christian church organizing an outreach program.

\footnotetext{
${ }^{1}$ B.D. Ehrman: Jesus, Interrupted, p.1.
} 
Inside our local church herself, we see believers who take position in opposition. They are convinced that Christ or Our Lady gives them messages. Their conviction is their watch word. They form pious societies, give them any name and co-opt people into them. Their spirituality is the spirituality of the founder. Their belief is the teaching of the founder. The only truth they accept is that propounded by the founder. Often the bible remains the resource material but read and interpreted to suit their quims, messages and visions.

In summary, our local church is attacked and hemmed in by two powerful and disastrous extremes: internally by fundamentalism/fanaticism and externally by traditionalism and sectarianism championed by fallen Catholics. The chart below makes our point clearer:

LOCAL CHURCH

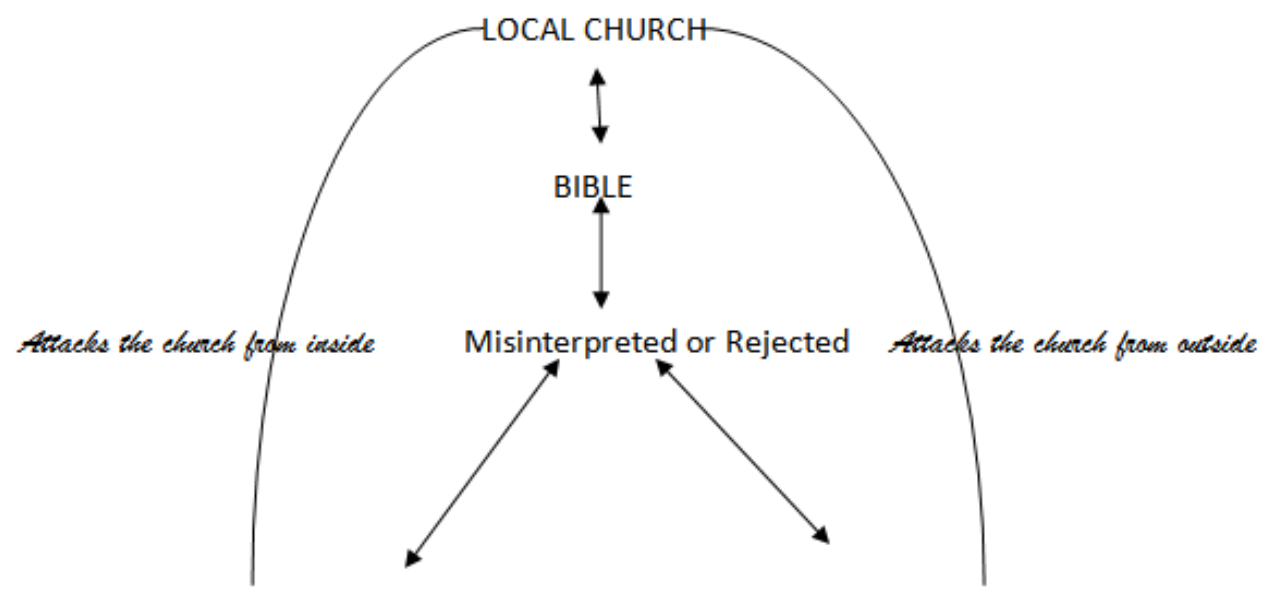

FUNDAMENTALISM/FANATICISM

TRADITIONALISM/SECTARIANISM

BIBLE Attacks the church from inside Misinterpreted or Rejected Attacks the church from outside FUNDAMENTALISM/FANATICISMTRADITIONALISM/SECTARIANISM

Fig. 1.0 showing the local church and her work of evangelization with the bible. Improper catechesis leads to misinterpretation (fundamentalism) or rejection (traditionalism/sectarianism).

Amidst all these stark realities, this paper documents that the problem is not with the bible but with the mode of presentation and also the mind-set of people of our time. X-raying the role of scripture and catechesis in evangelization is therefore the primary task of this work. By extension it also touches on the application of the scripture in evangelization while the task facing priests as communicators of the divine message remains further rubric for discussion. Since scripture transmits the inspired writings and catechesis impacts the knowledge to adherents based on the Church's experience both are taken in pari passu. Simple procedure is employed to ease our job. The key terms are given brief clarification. The scripture is then posited as the foundation of the Church's teaching. A brief excursus on the role of the scripture in the history of evangelization is given attention as a back-up for further studies. Detailed exposition is given to the application of the scripture in evangelization for more effectiveness leading to a clarion call for more proper interpretation and the task facing clerics on whom the onus of teaching lies. This is followed by conclusion.

\subsection{Scripture/Bible}

\section{A BRIEF LOOK AT THE KEY TERMS}

For the purposes and scope of this paper, we use the terms scripture and bible interchangeably. Etymologically, Scripture is from the Latin word scriptura which is itself from the Latin verb scribere meaning "to write". Ordinarily therefore scripture could be said to mean "the written". Within our context and locality, the scripture is synonymous with the bible. The word 'bible' is from the Greek word biblia (biblia) also in Latin. It is the plural form of biblion (biblion) which simply means book. The name "the books" without qualification, indicates the special position which these books occupied, and also shows the bible is a collection or library rather than a single literary composition ${ }^{2}$. The bible is called sacred because it is believed to have been written under the inspiration of the Holy Spirit. The books of the bible are said to be canonical because they are

\footnotetext{
2 J.L. Mckenzie: Dictionary, Pp. 95-96.
} 
enumerated in the authentic list of sacred books called the canon $^{3}$. They include the forty-six (46) books of the Old Testament and the twenty-seven $(27)^{4}$ books of the New Testament, first printed in 1450 by Guttenberg (Mainz). Simply stated therefore, we document with the Fathers of the Second Vatican Ecumenical Council that the scripture is "... is the speech of God as it is put down in writing under the breath of the Holy Spirit".

\subsection{Catechesis}

The word catechesis from the Greek katēchein (kathcei/n) is used to signify teaching or instruction in the law of God (Acts 18,25; Rom 2,18; Gal 6,6) ${ }^{6}$. The author of the letter to the Hebrews differentiates it from the kerygma and didaschalia. He calls it feeding children with milk rather than the solid food of justice (Heb 5,12-14; 1Cor $3,1-3)$.

The Church understands it to mean "an education of children, young people and adults in the faith which includes especially the teaching of Christian doctrine imparted, generally speaking, in an organic and systematic way, with a view to initiating the hearers into the fullness of Christian life" ${ }^{\text {"7 }}$ It is the name given to the totality of the Church's efforts to make disciples, to help men believe that Jesus is the Son of God so that believing they might have life in his name, and to educate and instruct them in this life, thus building up the body of Christ ${ }^{8}$.

In the primitive church, catechesis as seen in the epistles of Paul, Peter and James assumed dual meanings. First, it seen as teachings to converts from Judaism based on the holiness code of Lev 17-19 and the Jerusalem apostolic decree of Acts 15,19-21. Emphasis was on the acceptance of the Word of God as truth in contrast with idolatry. The expansion of the church to Syria, Asia Minor and Greece ushered in a need to teach converts from paganism and Hellenistic proselytes. In addition to abstentions, further moral instructions based on Psalms, Proverbs and Jewish ethical codes of Deut 30 were introduced ${ }^{9}$. In the first five centuries of the church it is primarily a pre-baptismal instruction given to adults. With the Germanic tribes won over to the church and many more conversion made daily, a new concept of catechesis emerged. The church got concerned with the problem of having to educate the large group of rude and unlettered converts on their newly embraced faith. Pastoral treatises written by bishops and monks at this period were the resource references for catechetical instruction.

It was Pope Gregory the Great who in his libri dialogorum introduced one typical approach in handing on the faith. The book is a collection of tales on the marvelous and miraculous cult of saints. From then, believers looked up to the local saints for a vivid illustration of the Christian life. Shortly after, liber regulae pastoralis was published as a pastoral manual for bishops to complement libri dialogorum.

From the $7^{\text {th }}-11^{\text {th }}$ centuries, teaching the truth of the scripture and the Church was the magna carta of the authorities of the church including Boniface $\mathrm{V}^{10}$, St. Gall ${ }^{11}$, St. Eligius ${ }^{12}$, St. Boniface ${ }^{13}$, Rabanus Maurus ${ }^{14}$, the

\footnotetext{
${ }^{3}$ Canon, from the Greek word kanwn means a measuring stick or rod. Certain conditions were stipulated which the writings in circulation claiming orthodoxy must meet before it is accepted as truly inspired. The books that meet these conditions are known as the books of the canon which we call the bible today. They include the proto-canons (o 'molegoumenoi) and the Deutero-canons (avmfibaloumenoi).

${ }^{4}$ It is necessary to give credit to the brains behind the numeration of chapters and verse which we cite today. Before Christianity, the TaNaK or Hebrew bible was divided into verses and sections for synagogue reading. The modern division and numeration of chapters is generally attributed to Stephen Langton (+1228), Professor at Paris and later Archbishop of Canterbury. He probably employed an existing division. The modern numeration of verses in the OT was made by Sanctes Pagnini, O.P. in his Lt Bible of 1528. The numeration was adopted by Robert Etienne, a Paris printer and so numbered the verses of the NT in his edition of 1555.

${ }^{5}$ D. V. n. 9

${ }^{6}$ F.X. Murphy: “Catechesis 1", p. 208.

7 John Paul II: Post-Synodal Exhortation, n. 18.

${ }^{8}$ The Catechism of the Catholic Church, n. 4

${ }^{9}$ The Didache and the Letter of Barnabas supply examples of the primitive catechesis in the guise of the two ways of life and death (Did.), or of light and darkness (Bar.). All were based on Jewish synagogue practice.

${ }^{10}$ In his letter to Edwin, King of Northumbra he gave a program of Catechesis detailing that pagans were to be taught the emptiness of idols, and the importance of belief in creator God and His son Jesus as savior before they were baptized.
}

${ }^{11}$ He propounded a catechesis faithful to De catechizandis rudibus of St. Augustine of Hippo.

1212 Emphasized the role of parents in handing on the faith.

DOI: 10.9790/0837-2107052031 $\quad$ www.iosrjournals.org $\quad 22 \mid$ Page


councils of Clovesho (747), Frankfurth (794) and Arles (813). Later $12^{\text {th }}-15^{\text {th }}$ centuries sequent to the revival of commerce in Europe with its accompanying growth of town and urban life, the obligation of explaining to the people on Sundays the articles of faith in simple and clear fashion was imposed on the parish priests ${ }^{15}$. The need brought about by urbanization also gave rise to Mendicant, Franciscan and Dominican Orders as remarkable effort to adapt new catechetical methods to face the challenges. There were also many devotional works containing a kind of catechesis especially in the $15^{\text {th }}$ and $16^{\text {th }}$ centuries. Thus the fifth Lateran Council (1514) recognized a general need for better religious instruction. School masters were the major instruments used to pass on the truths of the faith. it was actually Luther's over-arching influence in large of areas of Germany through a medium of effective catechesis that woke the church from her slumber. Since then catechism came to refer to a book both the manual used by the catechist and the simpler text in the hand of a child. The Church at this time was bent on theological accuracy in her catechesis to keep clear the essential differences in doctrine that separated the Church from the new sect ${ }^{16}$. From this time until Trent including Robert Bellarmine's catechism ${ }^{17}$ up until the $20^{\text {th }}$ century catechesis centers around the idea of the kerygma or good news of salvation. Thus the creed, code and cult are integrated in a catechesis which is Christocentric, sacramental, and Biblicohistorical ${ }^{18}$.

This brief history gives us a common denominator in the concern of the Church from shortly after Christ until date, namely, to help adherents to a fuller understanding of the Catholic faith and to get him practice his faith to any extent possible. Often we limit our understanding of catechesis to the instructions given to the catechumen or generally to children intending to receive the sacraments. Catechesis should be an on-going exercise. 1Pet 3,15 enjoins us to have reasons to give for our hope. Catechesis disposes us to listen to the good news of our salvation in Christ and to solicit the answer of faith. It is not simply intellectual truths drawn from God's word but God's own revelation retold and His plan of salvation announced with all the striking, challenging, and moving power that lies in its very content with Christ always standing at the center of the whole message ${ }^{19}$. Catechesis is a fundamental obligatory function of the Church. Those who hear the word and attracted to the faith is thereby given the opportunity to know in deeper fashion the faith they have embraced.

\subsection{Evangelization}

In its basic sense the term has meant, from the beginning of Christianity, the communication of the Gospel of Jesus Christ. In its modern sense it designates the process by which a person is led to make a commitment to Christ, dedicate himself to a Christian way of life and become a vital member of the local church. The general aim of evangelization is to convert the unchurched masses through missionary efforts. Every age and place have peculiar system that works for it. The message is basically the same but the success of evangelization is dependent on the ability of the evangelizers to discover the best method suitable in a given place and epoch. Apart from Catechesis, retreats, homilies, sermons, sunday evening instructions are other avenues for handing on the Word of God.

\section{STATUS QUAESTIONIS}

Matt 28,19 stipulates the mandatum magnum of the Lord to his followers "Going into the world therefore make disciples of all nations, baptizing them in the name of the Father and of the Son and of the Holy Spirit" 20 (poreuqe,ntej ou=n maqhteu,sate pa,nta ta. e;qnh( bapti,zontej auvtou.j eivj to. o;noma tou/ patro.j kai. tou/

\footnotetext{
${ }^{13}$ He provided a link between Romano-Anglo-Saxon tradition and early Carolingians. His missionary effort was characterized by fidelity to Rome and a spirit of adaptation to local customs where this could be harmonized with the Christian life. He always looked to the scripture as the substance of his teaching.
}

${ }^{14}$ He wrote a treatise De disciplina eccclesiastica aimed at showing a method of instructions for pagans asking for baptism.

${ }^{15}$ The Council of Lambeth (1282) provided a brief summary of the instructions priests were to give their people.

${ }^{16}$ M.E. Jegen: “Catechesis II", p. 211.

${ }^{17}$ This was written at the order of Pope Clement VIII for use in the Papal States.

${ }^{18}$ The Church went beyond catechesis for children to delve into other currents in the life of the Church. Notable movements like the liturgical movement, advances in biblical scholarship and in theology and the impetus given to a deeper Christian life and worship by such encyclicals as Mystici Corporis of 1943, Divino Afflante Spiritu of 1943 and Mediator Dei of 1947 all gave a new definition to catechesis.

${ }^{19}$ M. Ramsauer: “Catechesis”, p. 216.

${ }^{20}$ See also Mark 16,15; Luke 24,22 and Acts 1,8.

DOI: 10.9790/0837-2107052031 $\quad$ www.iosrjournals.org $23 \mid$ Page


ui ou/ kai. tou/ a'gi,ou pneu,matoj...). Realization of this divine mandate has been the primary and utmost concern of the Church in every epoch from the apostolic times till date both universally and locally. Enormous success has been registered. From twelve (12) men, some of whom were unlettered (Acts 4,13) Catholicism numbers over one (1) billion adherents from all works of life and professions, thanks to God's grace made accessible through the power of His word and sacraments passed on through His church after proper catechesis. Despite this glorious and happy success, problems and challenges still persist. There are still many people out there especially in our local church who are yet to experience the truth of the gospel message. Some who were once with us have gone their separate ways with other denominations. Proliferation of ecclesial bodies remains an incipient problem that urgently questions the effectiveness and resilience of the our local church's catechetical methods. If one is truly convinced that Catholicism holds the truth to salvation since Christ formed only one and unique $\mathrm{Church}^{21}$ then it will be as difficult for such to fall away from the faith as it is difficult for him to eat a poisoned food. Experiences have proven beyond doubt that we have more of the elderly in the catholic church today. We are losing most of our youths to our separated brethren especially in the institutions of higher learning ${ }^{22}$. More worrisome is the fact that many are getting more disinterested in the Church and are rescinding to traditional practices. In the cities, the story is not different. Often economic situation in the country is blamed for it. There is more to the truth than that surely. We lack conviction and commitment in most of our Catholics. This is not unconnected with the mode of catechesis and lack of continuity leading to insufficient knowledge and in some cases complete ignorance of the truth of the bible.

\section{THEBIBLEASTHE FOUNDATIONOFTHECHURCH'STEACHING: A HISTORICAL EXCURSUS}

St. Irenaeus teaches that:It is the one and the same father of the household (oikonomos) who lords it over the whole house, giving an appropriate rule to the slaves and uneducated, but to the freemen and those justified by faith communicating introductory writings suitable, and unlocking the inheritance to the children ... namely, the Word of God, our Lord Jesus Christ ${ }^{23}$.The bible is the authority and foundation of the Church's teaching because just as revelation itself becomes a norm by means of the bible, so the bible becomes authoritative because it witnesses to the revelation ${ }^{24}$. The Fathers of the Second Vatican Council describes the scripture as the depositum fidei ${ }^{25}$. They teach that Sacred Theology relies on the written Word of God, together with Sacred Tradition, as on a permanent foundation ${ }^{26}$. The Church holds the scripture as the very soul of theology ${ }^{27}$. Thus the Church receives her faith from the bible and from Tradition which is the living teaching authority of the Church as it is has existed from its foundation by Jesus Christ. Thus Catholicism as a Church of sacraments ${ }^{28}$ as well as of the Scripture, she places the authority of the Scripture within the broader context of the Church $^{29}$. In fact the Tridentine Council defines that the gospel which Christ promulgated and ordered to be preached was the source of all saving truth and rule of conduct and this truth and rule are contained in the written books and unwritten traditions which have come down to us ${ }^{30}$. The role of the scripture in the church's history of evangelization proves just this. The citation of the OT by most NT authors underscores the primary role of the scripture in evangelization in the apostolic times ${ }^{31}$. Different conciliar documents that were postulated to correct some heretical interpretations of the bible and even to protect the bible through canonization of the approved books in the face of Gnostic claims demonstrate the primacy of scriptural role in

\footnotetext{
${ }^{21}$ L. G. n. 2

${ }^{22}$ As the Rector of the Holy Family Youth Village hostels I must praise the vision that brought the idea of that hostel to reality. Through Sunday catechetical instructions, we have been able to win back some catholic students who are living in the hostels. The danger still looms among many others who are outside the hostels. Some of them have their lecturers, friends and even roommates as pastors. There are outreach programs organized now and again by these sects with sweetish tongued pastors who promise them manna from heaven.

${ }^{23}$ Adv. Haer., 14,14.2.

${ }^{24}$ J.K.S. Reid: The authority of Scripture, p. 231.

${ }^{25}$ D. V. n. 10.

${ }^{26}$ D. V. n. 24

${ }^{27}$ Leo XIII: Providentissimus Deus, Pp. 269-292; Benedict XV: Spiritus Paraclitus, Pp. 385-422; Benedict XVI: Word of God in the Life and Mission, n. 31.

${ }^{28}$ L. G. n. 1

${ }^{29}$ G. Fogarty: "Biblical Authority in Roman Catholicism", p.1023.

${ }^{30}$ Fogarty: Ibid. Pp. 1023-1024.

${ }^{31}$ It is good to note that for the NT authors, scripture meant the OT
} 
evangelization among the early Christians.In the middle ages even with the appeal to the threefold spiritual sense of the scripture: tropological, anagogical, and allegorical; commentaries on the sacred pages especially that of Albert the Great and Thomas Aquinas were all in effort to communicate the messages of the Word of God to believers. Jerome's translation of the bible into Latin (Vulgate) went a long way to ease the problem of being acquainted with the original languages of the bible before interpreting it. With the challenges coming from the sola scriptura of the Reformation times, the Church still upheld the primeval position of the Scripture in evangelization but reasserted her role in preserving the apostolic teaching through insistence on proper interpretation of the bible. According to Engen, "The conviction that Scripture formed both the source and the content of divine revelation underlay the whole of medieval European civilization ... Scriptural texts were invoked at almost every point in medieval civilization" 32 . Public worship, prayers said by monks and homilies by priests were all scripture based. Canons in cathedrals and collegiate churches were to sing the psalms and canticles of Scripture at appointed hours. The role became so recognized that scripture emerged as a separate discipline in theological studies.

In the modern epoch including the age of enlightenment and even the contemporary times, the Scripture has not lost its primacy as a resource and reference book for the evangelization of peoples.

In our local churches, the role of the Scripture is very much conspicuous. Like in the medieval ages, Scripture is used in both the religious and civil circles. It is however concernful to note that the rate with which the bible is cited is not proportional to the real life we witness in the society. Many are Christians only in the four walls of the church. Some have the bible on the one hand and corruption on the other. For many, the bible verses are easiest ways of taking advantage of the less informed. There is therefore urgent need to address the mode of presentation of the Word to have desired salvific and moral influence on the believers.

Despite this factual truth regarding the pivotal role of the bible in evangelization, we must not be blinded to the fact that the bible is the Word of God in the writings of men.

\section{THE BIBLE IS NOT DEVOID OF HUMAN IMPERFECTIONS}

In the Scripture, we have the "Word of God" in words of men. They are preserved and handed on. They are also copied and transcopied as the papers wear out with time. These copyists were human and their work was not saved from error by the very fact that they were working on the divinely inspired Word of God. A scribe might be tired or confused while copying from a manuscript. Evidences of voluntary and involuntary errors, omissions, and additions abound. 1Cor 5,9; 2Cor 2,3-9; 7,8-12; Col 4,16; 1Chr 29,29; 2Chr 9,29 etc all refer to lost books and so by implication prove that not everything is in the bible. Proper interpretation is required even for the contents and it is the responsibility of the Church and not for an individual (2Pet 1,19-21).

Our already translated and relatively well-ordered English Versions are deceptive in giving the impression that the Bible in Hebrew and Greek has been very simple, straight forward, well-ordered and without problem. Not at all; one only has to consider the copious footnote explanations and commentaries in these English versions; - they are translators' attempts at lessening the confusions and uncertainties which often arise from textual difficulties and problems.Since our people are already pushed into accepting everything in the bible literally and doubting whatever that is not found in the bible, the danger is that unless proper catechesis is given, we may risk habouring licensed schismatics and fanatics. We always talk of the bible as literature. This raises the problem as to when and how it came to be. Obviously, it did not just come up as a written document. It must have undergone some stages of development. Scholars have tried differently to grapple with this problem. Nyberg believes that traditions were handed down orally in the Ancient Near East and scarcely in writing. He insists that before documentation in writing, the works have always existed orally and continues that way even after it has been committed to writing. He holds that this is also true for the OT which until the exile had an oral prehistory in different places. It's written form is the creation of postexilic Jewish community. The NT is not devoid of the same problem. It existed as an oral tradition before it got penned down as document.

Engnell and Birkeland footnoted Nyberg and teach that the OT was handed down for years as oral tradition as complete oral literature. Nielsen agrees with Nyberg and developed his own hypotheses based on Nyberg's position. Windengren expressed a contrary view. He contends that oral tradition is of little importance and influence. He thinks that oral tradition is present only in exceptional cases. He is of the view that the texts were written and transmitted from the earliest stages.Mowinckel steered a middle course. He preferred to talk of the oral development from individual unit to collection and then fixed written text with canonical authority. Other scholars like Gunneweg, Hempel and Stuhlmueller insist on the existence of the traditions side by side.

\section{Oral and Written Tradition}

32 J.V. Engen: "Biblical Authority in the Medieval Church", p. 1028. 
In the ancient world, communication was mostly oral. Unlike our own age when people easily look up matters in books, the memory of the ancients were more developed. Facts were related through stories told in communal settings. On special feast days especially, religious leaders in particular recited ancient traditions. In schools masters gave and interpreted the law with examples.Oral cultures were not bent on specifity with dates. This is because they had general belief that the period between creation and later times were marred with evils. Only reunion with creation times gets one into affinity with the divine. Thus events were centered on sacred times of the year when people and nature renew themselves like the first beginning.The OT is replete with "wonder" or wonder stories eg. the strength of Samson deriving from his hair (Judges 14-16) or the power of Elisha to lift a heavy axe from the bottom of a lake ( $2 \mathrm{Kgs} 2$ ). These stories are purely legendary with heroic colour in their retelling over the years. The real intention of the narrator is to show that God gave these people special and supernatural help.

Thus in ancient times, the historian as well as OT and NT authors:

i. Record the traditions of the tribe or nation as they interpret them.

ii. $\quad$ Adopt oral sources with few written documents

iii. Often include several parallel versions of the same story

iv. Furnish their records with approximation of dates since there is hardly exactness in dating

v. Depend strongly on fixed motifs of descriptions that can be applied to all similar situations.

vi. $\quad$ Adopt past history to explain convictions for the present time or for a particular point of view.

In his 1943 Encyclical entitled "Divino Afflante Spiritu"; Pius XII did urge Catholic Biblical Scholars to work hard towards restoring the texts of the Bible from errors, glosses and omissions. This gave impetus to Higher and Textual criticisms of the Sacred texts. Having seen that the old tradition has different varieties, oral and written and the myriad forms they take in transmission and consequent alterations in time, the OT and NT scholars must be ready to keep aside the present unity seen in the books of the canon, designed to shape our faith, in order to discover how Israel grew, changed and deepened her faith. Higher Criticism helps us do this with her three literary tools: source criticism (the problem of whether there are written documents behind a given text); form criticism (to take care of the excesses of some source critics by defining the form of literature used by a text and setting the unit) and Tradition Criticism (the quest for understanding the growth of a tradition over time from its original form to its incorporation in the final text).

\section{TEXT TRADITION.}

There was a certain level of standardization of the texts of the Bible at the time of Christ. However these retained most of the major mistakes made by the copyists. Each of these text traditions had its own peculiar characteristics, manifesting a lot of the type of people the Jews mixed with and showing certain elements of the fact of their freedom. This is with particular reference to the Babylonian Text Type. These Text Traditions included

1. The Babylonian Jews Text Type - having a shorter edition of the Pentateuch.

2. The Egyptian Jews Text Type------ richer and more copious or expanded

3. Palestinian Jews Text Type-------- better in the books of the prophets

In A.D 100, the Rabbis saw the need to select through the various Texts Types and tradition so as to establish one and authentic Text of the Old Testament They also saw the need to vocalize the texts by putting vowels and separation of the words. They also counted the number of words in a book, even the number of syllables and sections in a book and documented them. These were just to prevent too much variation from the original should these text be copied out.The exposition above necessarily invites an urgent response. It calls for a footnoting of the clarion call by Pope Pius XII if the church must be sheltered from the fanaticism and fundamentalism bedeviling our Christendom today. Unless something is done, the church risks losing her members as time will most unfortunately prove all aberrated prophecies wrong. The alternative would be for the people to see the church as a cheat and deceit. The option very near is to disbelieve the church and relapse back to traditionalism.I believe that Africa must take the lead in hearkening to this clarion call by His Holiness. The fanatical spirituality and quest for miracles leading to gullibility of all claims call for immediate and urgent action on the part of the Local Church. Most Africans are victims of exploitation by gullible Pentecostals and priests in the name of evangelization. The bible is quoted to support their lies to make cheap money. In Africa today, religion and politics are now the easiest way to make money with less stress. The researcher is convinced that the Church in Africa must rise to the challenges of this licensed robbery and be on the side of the truth which she is called to uphold. 


\section{THE ROLE AND MODE OF PRESENTATION OF THE MESSAGE IN AFRICA}

The belief of the average Christian in the street is that the bible is the Word of God. It has come to such a level that the credibility of one's claims to the truth of the faith is directly proportional to its proof with a biblical quotation. For many, whatever is not in the bible is hardly true. Preachers of the Word are therefore encouraged necessarily to give some biblical touch to their reflections and homilies. Citing chapters and verses in a parrotic way can hardly impact on the soul. A lot more is needed.

i. $\quad$ Presenting a Credible Story by Reading the Scripture as a Narrative ${ }^{33}$

Evangelization in the $21^{\text {st }}$ century calls for a presentation of a credible narrative of human existence. The story that Christians have told and must continue to proclaim remains a powerful narrative of salvation. But it is a narrative that must be presented in a way that our contemporaries can see the story of their life in the story we tell. To be a good narrative, the story must have a beginning, middle, and a conclusion. It must explain who we are by reminding us where we have been and where we are going. It must provide us with models we can and want to imitate. Most essentially, it must clarify the meaning of human existence. Reading Scripture as a narrative provides us with a way to understand our lives in light of the narrative that Scripture tells. This renewed appreciation of the narrative dimension of the biblical text has important implications for the New Evangelization. Firstly, it reminds us that Scripture is a narrative- a story that begins with creation and ends with its restoration; a story in which people can discover the meaning and purpose of their lives; a story that roots us in the past and gives us hope for the future. secondly, this narrative approach provides us with an example of how we can evangelize today. For by becoming familiar with the scriptural narrative, we find new ways to tell an old story; we find new ways to explain the problems we face and how to respond to them; and we gain new insight into how we ought to live. Our grand fathers in the faith adopted this method and it was very effective. In Acts 13,16-41 for instance, Paul evangelizes by telling a story that enables his audience to make sense of the present in light of its history. Rom 9-11 is another example. Markham and Ruparell opine that biblical truth must be translated into what is acceptable to the modern mind ${ }^{34}$.

\section{ii. $\quad$ Expressing Catholic Faith Biblically}

Raymond Brown observes most correctly that Catholics are often nonplussed when tenets of their faith are queried by biblical fundamentalists, sometimes polemically, but more often in conversation ${ }^{35}$. We are losing most of our young Catholics to our separated brethren because of the false claims that the teachings of the Church are not found in the bible. Their level commitment and conviction doubles as soon as they leave the Church to join these other simply because the bible is referenced in support of almost every teaching. The interpretation could be wrong but at least they have citations to back up their message. Since we have been taught from origin that the bible is the Word of God, they have no option than to accept what they are told. The naked truth is that majority of Catholics are deficient in the knowledge of the bible ${ }^{36}$. The decadence of the number of young catechumens baptized annually in the Catholic church with a geometrical rise in the number that jump into Pentecostalism is enough concernful sign to buttress my point. We have items of our faith like the Mass, sacraments, Pope, Mary and saints explained in a phraseology from catechism books but nothing in training equips us to handle objection that such beliefs are non-biblical ${ }^{37}$. Swapping proof texts or attacking the fundamentalists or trying too suddenly to convert them is actually not the solution. The bible enjoins us to have reasons to give for our hope (1Pet 3,15). Undoubtedly, Catholics would feel more self-confident if they understood the bible relatedness of the doctrine being queried, and biblical fundamentalists might at least realize that their understanding of Catholic doctrines is too simplified if those doctrines were intelligibly phrased in a biblical atmosphere. For instance, it would be wonderful for an average Catholic to know that the same gospel of Mark that listed some people as brothers of Jesus (Mark 6,3) reveals the name of the real mother of some of the men in a latter chapter (Mark 15,47-16,1).

iii. $\quad$ Translating Biblical Messages to Life

\footnotetext{
${ }^{33}$ I am indebted to Frank J. Matera in his address to the Catholic Bishops of the United States of America. Frank is The Andrews Kelly Ryan Professor of Biblical Studies at The Catholic University of America, Washington, DC. ${ }^{34}$ I.S. Markham and T. Ruparell: Encountering Religion, p. 76.

${ }^{35}$ R. Brown: 101 Questions \& Answers on the Bible, p. 137.

${ }^{36}$ The situation in our Institutions of higher learning is increasingly worrisome. They enroll into schools as Catholics but they graduate as Pentecostals.

${ }^{37}$ I published a book titled "Bible References for Basic Catholic Teachings. A Pocket Concordance". It contains biblical references for almost all the teachings of the Church. It also has a chart to help believers go through the bible in one year.
} 
The linkage of mission with charity witnessed in Africa ${ }^{38}$ during the missionary era underscores the importance of translating biblical messages to real life. Biblical messages are not structured to be conceptual or just read as something that happened years ago without any reference to the present. In Luke 4 as in many other NT texts, Jesus' preaching convicted his listeners eliciting some reactions. In Acts 2,32 the Jews listened to Peter and asked what they would do. They felt like undoing their wrong deeds against Christ. Unless biblical messages are rendered applicable to life situations, we may end up sounding intellectualistic. The homilies of our Archbishop against false prophecies about two years ago, still remain fresh in my memory as I still picture how his miter was moving when he demonstrated how a spirit cast out from a tree in a family can jump and stay on the roof. In the words of Jegen, "the Christian mystery is present as event rather than idea. God's plan of salvation of salvation, centered in Christ is presented as evoking a return response of love from the human family called to union with God through Christ in his Church"39. Faith is the answer to the proclamation of the Christian message. It involves preaching the word in a way to prepare the ground, sowing the seed of God's word and then develops the incipient faith through proper catechesis.

\section{PROPER ROLE CALLS FOR PROPER INTERPRETATION THE POWER OF CATECHESIS}

2Pet 1,20 warns that the words of the scripture did not come to be by personal interpretation (tou/to prw/ton ginw,skontej o[ti pa/sa profhtei,a grafh/j ivdi,aj evpilu,sewj ouv gi,netai). A good understanding of the bible implies a good interpretation. This is why St. Peter warns that we must have reasons to give for our hope (1Pet 3,15). Again the greatest NT writer St. Paul admonishes us strongly against false teachings. In the words of J.K.S. Reid "Since Scripture is not merely inspired but inspired witness, the criterion between what is and what is not Scripture is to be found not subjectively ... but objectively by observing the content of what is written ${ }^{, 40}$. Unless there is proper interpretation, the Church may end up being a potential incubator for fundamentalists. Considering the trend of events today in our local church and the unqualified belief in the bible by our peoplethe need for proper interpretation becomes ever more urgent.Encouraging the people to read through the bible and memorize chapters and verses would be as good as memorizing Newton's laws of motion without its corollary mathematical formulas that apply it to life. The bible itself purposes some serious literary issues with attendant problems to one's faith. Myriads of aporias, inconsistencies and apparent contradictions can only come to par with adequate interpretation. For instance, there are stories of exorcisms in the synoptic gospels but not even a single case in the Fourth gospel. Again, how can one reconcile the fact that Paul in Gal 1,16-20 claims that he is not lying and that he did not consult with others after his conversion, nor did he see any of the apostles for three years. Even when he eventually did, he met only briefly with Peter and James. But then in the account given about his conversion in Acts 9,19-30 it is said that he spent some time with the disciples in Damascus after which he headed straight to the city where he met with the apostles of Jesus? Also, how can one reconcile the fact that in Mark 14,30 Jesus says that Peter would have denied him three (3) times before the rooster crows twice while in Matt 26,34 it is just before the rooster crows? Is it just once or twice? Mark 11 indicates that the cleansing of the Temple was at the last week of Jesus life whereas John places it at the beginning of Jesus' public ministry. Surely, the authors of Gal 3 and Matt 5,17-20 would need a good interpreter to explain their very parallel teachings on the Law and Faith! In John 13,36 Peter asked Jesus where he was going and also Thomas in John 14,5 did the same. Yet in John 16,5 Jesus upbraids his disciples that none of them has asked him where he was going. There are still many more issues raising questions and commanding serious need for clarification in the bible, both in the NT and OT. The two creation accounts in Gen 1 and 2 is another example. These few examples plus lots more underpin and underscore the urgency and necessity of interpretation if the message of God in His Word must not be misconstrued and misapplied. Unfortunately, reverse has been the case in our local churches. Our people have remained victims to deceits by wary pastors and priests who exploit the ignorance of our people to use the bible for easy money making. Think of tithing, seed sowing, healings and other good sounding ideas some clergy men develop to take advantage of the faithful to get money. In all, bible passages are cited in support. For tithe for instance, Mal 3,8-12 is cited in support. Hardly are people made to understand that we have ceremonial, civil and moral laws. In 1Tim 2,9-12 Paul has outrageous laws guarding women in the church. I wonder if these Biblicists do not see such and also enforce it in their churches. Pigs that ought to be unclean animals in the OT form part of the palate for even some of these clergy men of God while actually the bible forbids such. Until proper interpretations are given, our flock will very unfortunately remain at the mercies of the unquenchable and ever insatiable thirst of these vociferous

\footnotetext{
${ }^{38}$ F.A. Oborji: "Poverty and the Mission-Charity Trend. A Perspective from Matthew", pp. 87-101.

${ }^{39}$ M.E. Jegen: “Catechesis II", p.214.

${ }^{40}$ J.K.S. Reid: The Authority of the Scripture.
} 
clergy men. This is not just limited to Pentecostals. It is even getting worse in the Catholic Church especially among healers. So called prophetic messages and visions are all offshoots of this poor understanding of the messages of the bible. The result is that families are broken today, many wallow in darkness thinking that they are in the light. The orthodox teaching of the church is given up in preference to very poor and unfounded beliefs in dreams, visions, miracles and all.R.M. Grant (1963) succinctly documents that "...when scripture is regarded as completely sufficient for doctrine, and at the same time the needs of the contemporary situation are quite different from needs long past, some means has to be found for relating the ancient book to the thought and life of a later day. This task is performed by interpretation". It must be added that there cannot be proper interpretation without adequate research. This is because, researches connect the past with the present and underscores the future by opening up hidden treasures of a particular discipline. An ignorant pastor ends up a chronic and confused fanatic irrespective of his faith. A faithless but knowledgeable pastor is simply an empty gong. He is only intellectualistic and is better a professor than a pastor. A true pastor must have faith and knowledge and both are rewards of sound researches.Research is very necessary for the pastor if he must widen his purview. It brings him in contact with other fields of experience and enables him to be a master in his own field. The findings of the archaeological discoveries sets him on a footing to situating and understanding biblical claims. It arms him with academic tools to sift the wheat from the chaff. The pastor is a guide and so ought to know better his subjects. He is also a teacher and so ought to teach the fact. Research is the unique and only means to expand his view and be better equipped to lead, teach and direct others.Every discipline grows and develops. Biblical studies can never grow or develop without a corollary studies. As custodians of the bible, the pastors have the onus and impetus to lead in this biblical research revolution. Much has been done already in biblical research. Many more remain enigmatic. Consider for instance the pre-historical stories of Gen 1-11. Creation story is today challenged by the theory of evolution. Brown (1983) says that some may try to use paleontology to disprove evolution often on the assumption that the theory of evolution is incompatible with the thesis of a Creator God. In 1955 and 1959, according to Bailey (1978), Fernand Navarra, a French industrialist, designed to verify the medieval thesis that the resting place of Noah's Ark upon the mountains of ARRT (Gen 8,4) refers to Mt. Ararat on the Turkish-Russian border. There are seven different traditions as to the where about of the Ark. Only a thorough research can unravel such mysteries. Gasque (1966) teaches that the travels of Sir William Ramsay in the early $20^{\text {th }}$ century showed how the study of the ancient cities that were visited by Paul in his journeys clarified the details of biblical accounts. However, the ambiance information is general in character and is not specific. A reading through the bible meets one with many things yawning for clarification as these and only a thorough research/study will help.The reason and importance of research is underscored by the triangular flow of facts from the sender (author) to the receiver (audience at the time) and then the world of today. Only a good research can bridge the yawning gap existing between the three as we can see below:

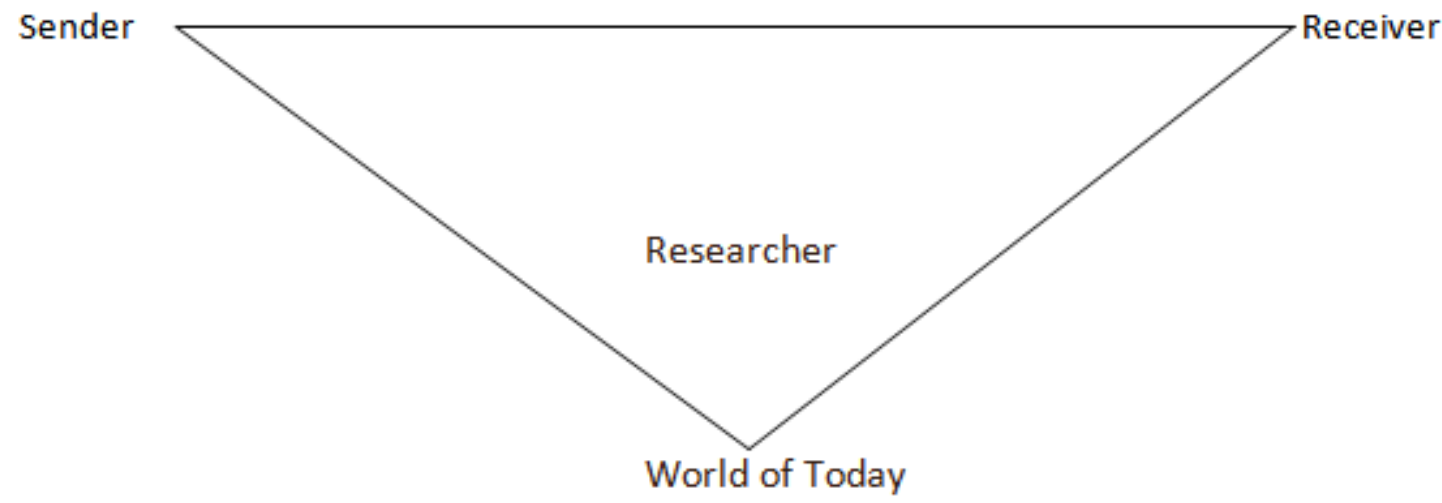

World of Today

By good research, the presenter means references to orthodox commentaries on the bible especially the ones on the readings at Masses. Pentecostal approach must be avoided completely in preaching the Word.

\section{RECOMMENDATIONS}

1. The African Church may need to consider sending more priests to study scriptures and Catechesis abroad and locally.

2. Many priests are jumping into "healing ministries" and "crusade apostolate". In as much as this should not be the case, the local church can also take advantage of this anomaly. They command the greatest 
number of audience. Orthodoxy, proper interpretation and application of biblical passages by these "charismatic" priests is of absolute necessity or else we risk running a system within a system. Insisting on further theological trainings for such priests will not be out of place since truly some of them have good intention but lack in the knowledge. Their proper and further training will aid catechesis immensely.

3. Proper regulations and guidelines for priest healers will surely curb lots of aberrations. If so called visions and prophecies could be forbidden by the Archdiocese, it will truly save her from the embarrassment caused by some who feign to have seen visions when actually they end up not only fooling the people but even getting them more confused. Many families are in disarray because of messages from acclaimed visionaries and prophets. Some have married people they would not have otherwise married simply because they were told that God ordained them to marry so and so. Syncretism and transposition of paganism into the church is becoming the order of the day. People are abandoning the God of sacramentals for the sacramentals of God. Concoctions are prescribed for the people who unfortunately take these things in faith not minding the possible hazards.

4. Establishment of a theological school that will be accessible to both the lay and clergy would be very helpful for thorough training on the appropriate interpretation of the Scriptures and Catechesis. A Diploma from such a school may be considered mandatory for every Catechist. This is because, leaders ought to be knowledgeable (Hos 4,6). A Catechist ought to teach and also lead with the Pastor. He must be knowledgeable or else the church will be in the dark.

5. Sunday evening instructions must be well organized and room given for people to ask their questions on doctrinal issues. Priests must take it up as a necessary duty. It is not a responsibility to be left for the Catechist, Charismatics or members of the Precious blood. Experience has shown that use of power points and projectors make greater impact.

6. Africa must take advantage of the new communication technologies to push on the message of the gospel. The impact Radio Sapientia in the Archdiocese of Onitsha has made underscores the magnitude of the impact of modern technologies. We are in a non-literate societies dominated by audition and vision orientation. Development of a Television Station would be a move in the best direction. The use of Whatsup, Instagram, Face Book, text messages and other modern means of communication must be encouraged especially among preachers who must exploit it as a means to reach out to people.

7. Church teachings and truths of the gospel message may need to be acted in movie form. Such interesting movies leave indelible mark on memories. The average Nigerian for instance remembers Living in Bondage, The Passion of Christ etc. More of such movies that portray the position of the Church on issues would be a serious break through.

8. The Catechism Book needs being updated with scriptural insights.

9. Religious Education in schools especially in our parochial schools must be taken seriously. The Church needs to find a way of liaising with the government on how to get Religious Education into the school curriculum with appropriate credit loads. Teachers of Religious Education must also be trained or else they use the period for worship and prayer. Unless this is done, we may be heading dangerously to the sad experiences in the Western world.

\section{EVALUATION AND CONCLUSION}

Scripture is the foundation of theology and also the fulcrum of the Church's teaching. The bible contains the message, while the Church passes it on through catechesis. This has been the case since the beginning of the Church including her troubled times, the golden era and even now. The fact is that every age has her attendant problems. The Church has continued to struggle to meet up with the challenges of each age ${ }^{41}$. She has never failed in her duty of bringing the gospel to the door steps of all and thereby giving birth to more children of God through her sacraments. The case is not different in the Africa. For greater success, she needs to impact more on the lives of our people in a new mode of evangelization. It must be the same true message of Christ presented in a new and befitting way.Consider for a moment why movies, literature, art, and pop culture are so important. On the one hand, they entertain us. But on the other, they are always telling us stories that capture our imagination. These stories are important because they help us to understand the story of our lives. And so, when we read novels, listen to music, look at art, or watch movies, we insert ourselves into the story world they create to understand something of the story of our life. The priests in Africa need necessarily to go back to their drawing board and take advantage of the pervading ways of communication to pass on the gospel message. It is only by means of this and insistence of catechetical instructions that our flock would be rescued from the dangerous and yet popular claws and jaws of priest prophets and pastors. The bible has been used to confuse many. Very many indeed get more and more confused as bible passages are cited in support of the least deceit. It is like the true

\footnotetext{
${ }^{41}$ Ecumenical Councils are convoked by the Pope precisely for this.
} 
message is getting more and more warped and swept under the carpet while false messages that sound good to the ear hold sway and grow daily. It is the submission of this paper that a good theological school, Television Station, sound catechesis and adequate use of modern means of communication will go a long way in not only salvaging our rather confused flock but will set them on right part to salvation. It will even win more souls for Christ in the African poise for a new evangelization.

[1] Adversus Haeresis, 14,14.2.

\section{REFERENCES}

[2] Benedict XV: Spiritus Paraclitus (15 September 1920) Acta Apostolicae Sedis 12 (1920) 385-422.

[3] Benedict XVI: Post Synodal Exhortation on The Word of God in the Life and Mission of the Church, Verbum Domini (30 September 2010).

[4] Brown, R. E. : 101 Questions \& Answers on the Bible. New York: Paulist Press.

[5] Ehrman, B.D : Jesus, Interrupted. Revealing the Hidden Contradicitons in the Bible. New York: Harper Collings Publishers, 2009.

[6] Engen J.V. : "Biblical Authority in the Medieval Church", The Anchor Bible Dictionary Vol. 5. Auckland: Doubleday Publishers, 1992, pp. 1028-1032.

[7] Fogarty, G. : "Biblical Authority in Roman Catholicism", The Anchor Bible Dictionary Vol. 5. Auckland: Doubleday Publishers, 1992, pp. 1023-1026.

[8] Jegen, M.E. : "Catechesis II", New Catholic Encyclopedia Vol. III. San Francisco: McGraw-Hill Book Company, 1967, pp. 209-215.

[9] John Paul II: Post-Synodal Exhortation, Catechesi Tradendae, n. 18.

[10] Leo XIII: Providentissimus Deus (18 November 1893) Acta Sanctae Sedis 26 (1893-1894) 269292.

[11] Markham, I.S. and Ruparell, T. : Encountering Religion. Malden: Blackwell Publishers, 2001.

[12] Mckenzie, J.L. : Dictionary of the Bible. London: Simon and Schuster, 1965.

[13] Murphy, F.X. : "Catechesis 1", New Catholic Encyclopedia Vol. III. San Francisco: McGraw-Hill Book Company, 1967, p. 208.

[14] Oborji, F.A. : "Poverty and the Mission-Charity Trend. A Perspective from Matthew", International Review of Mission, Vol. XCI No. 360, January 2002, pp. 87-101.

[15] Ramsauer, M. : "Catechesis Missionary", New Catholic Encyclopedia Vol. III. San Francisco: McGraw-Hill Book Company, 1967, pp. 215-218.

[16] Reid, J.K.S. : The authority of Scripture. A Study of the Reformation and Post-Reformation Understanding of the Bible. Westport: Greenwood Press, 1981.

[17] The Catechism of the Catholic Church, n. 4

[18] Vatican Council II. The Conciliar and Post Conciliar Document, A. Flannery ed. 1988. 